\title{
Repurposing mechanistic insight of PDE-5 inhibitor in cancer chemoprevention through mitochondrial-oxidative stress intervention and blockade of DuCLOX signalling
}

\author{
Manjari Singh ${ }^{1 \dagger}$, Sweta Kasna ${ }^{1 \dagger}$, Subhadeep Roy ${ }^{1}$, Sara Aldosary ${ }^{2}$, Abdulaziz S. Saeedan ${ }^{3}$, Mohd. Nazam Ansari ${ }^{3}$ and \\ Gaurav Kaithwas ${ }^{1 *}$ (D)
}

\begin{abstract}
Background: This study evaluates the anti-cancer effects of Tadalafil (potent PDE-5 inhibitor) in female albino wistar rats against $n$-methyl $n$-nitrosourea induced mammary gland carcinogenesis.

Methods: The animals were selected and randomly divided among four groups and each group contains six animals per group. The animal tissue and serum samples were evaluated for the presence of antioxidant parameters and the cellular morphology was studied using carminic staining, haematoxylin staining and scanning electron microscopy followed by immunoblotting analysis.

Results: On the grounds of hemodynamic recordings and morphology, n-methyl n-nitrosourea treated group showed distorted changes along with distorted morphological parameters. For morphological analysis, the mammary gland tissues were evaluated using scanning electron microscopy, whole mount carmine staining, haematoxylin and eosin staining. The serum samples were evaluated for the evaluation of oxidative stress markers and inflammatory markers. The level of caspase 3 and 8 were also evaluated for the estimation of apoptosis. The fatty acid profiling of mammary gland tissue was evaluated using fatty acid methyl esters formation. The mitochondrial mediated apoptosis and inflammatory markers were evaluated using immunoblotting assay.
\end{abstract}

Conclusion: The results confirm that Tadalafil treatment restored all the biological markers to the normal and its involvement in mitochondrial mediated death apoptosis pathway along with inhibition of inflammatory markers.

Keywords: Tadalafil, ER+ mammary gland cancer, Mitochondrial stress, PDE-5 inhibitor, N-methyl-n-nitrosourea, DUCLOX

\section{Background}

Distinct metastasis and resistance development by selfrenewing nascent cancer cells in response with the chemotherapy drug regimen and simultaneous radiations are still a main obstacle in cancer treatment for patients

\footnotetext{
* Correspondence: gauravpharm@hotmail.com; gauravk@bbau.ac.in ${ }^{\dagger}$ Manjari Singh and Sweta Kasna contributed equally to this work.

'Department of Pharmaceutical Sciences, Babasaheb Bhimrao Ambedkar University, (A Central University), Vidya Vihar, Raebareli road, Lucknow, UP 226025 , India

Full list of author information is available at the end of the article
}

nowadays [1]. Tadalafil is a known phosphodiesterase-5 (PDE-5) inhibitor, which have anti-cancer effects in various types of cancer [2]. In the search of molecularly targeted compounds that have the structure similarity with the known anti-cancerous drugs like viscristine, vinblastin, vindesine, vinorelbine, leuprolide and geserelin got tremendous attention due to the expression and regulation of the important signalling pathways [3]. In the last decade, Tadalafil used to inhibit the myeloid derived suppressor cells (MDSCs) and restore the T cells in cancer patients as compared to the normal peoples [4].

(c) The Author(s). 2019 Open Access This article is distributed under the terms of the Creative Commons Attribution 4.0 International License (http://creativecommons.org/licenses/by/4.0/), which permits unrestricted use, distribution, and reproduction in any medium, provided you give appropriate credit to the original author(s) and the source, provide a link to the Creative Commons license, and indicate if changes were made. The Creative Commons Public Domain Dedication waiver (http://creativecommons.org/publicdomain/zero/1.0/) applies to the data made available in this article, unless otherwise stated. 
PDE-5, PDE-6, PDE-9 are the predominant active isoform of ubiquitously distributed metallohydrolases constitute of 11 distinct gene families, which initiate the sequential lcleavage of cyclic adenosine monophosphate (cAMP) and cyclic guanosine monophosphate (cGMP) into their intermediate inactive 50 derivatives and 5GMP. It ultimately regulating the amplitude and duration of their intracellular downstream signaling mechanism [5]. This inhibition of cGMP conversion leads to activate protein kinase $\mathrm{G}$ and map kinase pathway of apoptosis and also simultaneously affect cancer cell growth and adhesion, mitochondrial energy homeostasis, neuronal signaling and muscle relaxation in systemic vasculature, prostate, heart, brain, lungs and platelets [6]. In previous literature, it was reported that PDE-5 inhibition produced caspase dependent apoptosis of B-cell chronic lymphocytic leukemic cells [7]. Various preliminarily studies also demonstrated that PDE- 5 inhibitors can induce apoptosis by activation of cGMP and nitric oxide (NO) in cancerous cell [8]. In recent findings, indole derivatives have the potency to treat mammary gland cancer and Tadalafil also have the indole moiety in its structure, which ultimately reveals its molecular mechanism [9]. It was reported that the expression of PDE-5 was significantly high in the malignant breast tumors as compare with normal breast tissues and benign tumors [10]. Consistently increased PDE-5 expression has also been reported in a variety of mammary gland cancer cell lines (MCF-7, T47D, HTB-26, MDA-MB231), which gives the rationale to assess the anticancer effects of PDE-5 inhibitors in carcinogen induced animal model and check the involvement of reactive oxygen species (ROS), death receptor and mitochondrial signalling as part of the combinatorial apoptosis mechanism. Based on the previous literature, we hypothesize to evaluate the effect of tadalafil upon carcinogen induced $\mathrm{ER}+$ mammary gland carcinoma in vivo model.

\section{Methods}

\section{Drugs and chemicals}

Tadalafil (API) was procured from the Sanofi Aventis as a gift sample followed by FTIR analysis to establish its purity. N-methyl-n-nitrosourea (MNU) (Sigma-Aldrich, N1517) was procured from Sigma Life Science Aldrich Co. 3050 Spruce Street, St. Louis, USA. Other chemicals were purchased from Himedia Pvt. Ltd., Sigma Aldrich and Amresco.

\section{In vivo study}

The study protocol was approved from CPCSEA guidelines for laboratory Animals and Ethics, Government of India (IAEC/SHIATS/PA16III/SSPG19). Female albino wistar rats of $100-120 \mathrm{~g}$ were used for this study and collected from the central animal house facility of Sam Higginbottom University of Agriculture, Technology and
Sciences, Naini Allahabad, India. All animals were randomized among four groups having eight animals each. Carcinogenesis was induced by single tail vein injection of MNU on day $1^{\text {st }}$ in each animal. MNU was dissolved immediately before use in glacial acetic acid and water $(\mathrm{pH}$ 4.5-5). The experimental groups were randomized as follows: group I (normal control, saline $3 \mathrm{ml} / \mathrm{kg}$, p.o.; group II (toxic control, MNU $47 \mathrm{mg} / \mathrm{kg}$, i.v.); group III (Tadalafil $2 \mathrm{mg} / \mathrm{kg}$, p.o. + MNU $47 \mathrm{mg} / \mathrm{kg}$, i.v.) and group IV (Tadalafil $4 \mathrm{mg} / \mathrm{kg}$, p.o. + MNU $47 \mathrm{mg} / \mathrm{kg}$, i.v). Tadalafil was administered from 7 th to 110th day at the dose specified above. At the end of study, animals were sacrificed for the collection of mammary gland tissue under ketamine hydrochloride $(100 \mathrm{mg} / \mathrm{kg}$, i.m. $)$ and diazepam $(5 \mathrm{mg} / \mathrm{kg}$, i.m. $)$ combination as anaesthesia.

All the animal experimental procedures follow the ARRIVE guidelines.

\section{Changes in hemodynamic recordings}

The hemodynamic changes were recorded using the Lab Chart Pro-8 (AD Instruments, Australia) instrument according to the methods elaborated by us previously $[11,12]$.

\section{Effect of Tadalafil upon morphological changes Whole mount alum stain}

Rats were sacrificed after completions of study and forth mammary gland tissues were excised and fixed for a minimum of 2 days in Carnoy's fixative solution followed by staining with carmine solution $(1 \mathrm{~g}$ carmine and $2.5 \mathrm{~g}$ aluminum potassium sulfate in $500 \mathrm{ml}$ water). The fixed glands were hydrated with 90, 70, 35 and 15\% ethyl alcohol and then rinsed with water for $5 \mathrm{~min}$. The glands were then dehydrated progressively in 35, 70, 95 and $100 \%$ ethanol, dipped in xylene for 2 days and mounted on glass slides. The sections were examined for the identification of angiogenesis $[13,14]$.

\section{Histopathological studies}

Thin section $(5 \mu \mathrm{m})$ of mammary glands tissue was cut using microtome and fixed overnight in 10\% hank's balanced salt solution (HBSS) buffered formalin which further used for representative gross morphological and histological features of haematoxylin and eosin (H\&E) stained paraffin sections of the mammary glands tissue $[15,16]$.

\section{Scanning electron microscopy (SEM)}

Sodium cacodylate and HBSS buffer based $\mathrm{HCl}$ collagenase hyaluronic acid enzymatic digestion method was used for preparation of tissue before SEM analysis. The entire methodology was performed according to methods elaborated by us previously [17]. The sample was dried with increasing grade of acetone $(70,80,90$ and $100 \%)$. All the acetone specimens were dehydrated 
and replaced by exchange of soak/flash liquid $\mathrm{CO}_{2}$ fluids with ethanol or acetone by critical point method $\left(31^{\circ} \mathrm{C}\right.$ and 74 bar). Samples were further processed by platinum coating, which has been examined under $\operatorname{SEM}(\mathrm{X} 1000)$ (JEOL JSM-6490LV) [15, 18].

\section{Effect of Tadalafil upon oxidative stress markers}

The antioxidant parameters were evaluated using tissue homogenate $(10 \% \mathrm{w} / \mathrm{v})$. The homogenate was prepared in $0.15 \mathrm{M} \mathrm{KCl}$ and the same was centrifuged for $15 \mathrm{~min}$ at $4{ }^{\circ} \mathrm{C}$. In thiobarbituric acid reactive substances (TBARs), malondialdehyde (MDA) forms a 1:2 adduct with TBAR and produce the reaction which can be measured by spectrophotometer at $540 \mathrm{~nm}$. For superoxide dismutase (SOD), the inhibition of pyrogallol auto-oxidation was measured. The absorbance was measured at $420 \mathrm{~nm}$. Catalase catalyzes the decomposition of hydrogen peroxide to water and oxygen. The absorbance was measured at $250 \mathrm{~nm}$. Glutathione was measured using Ellamanis reagent (DTNB), when DTNB reacts with GSH then 5 thionitrobenzoic acid (TNB) and GS-TNB was formed. The absorbance was measured at $410 \mathrm{~nm}[19,20]$.

\section{Serum NO level}

For NO estimation, same proportion of serum isolated from animal blood and Griess reagent were mixed and incubated at $37^{\circ} \mathrm{C}$ for $30 \mathrm{~min}$. The reaction was proceeded at room temperature, and the absorbance was read at $540 \mathrm{~nm}$ using UV-visible spectrophotometer (Cary 60, Agilent Technologies, CA, 95051, US). The standard curve was plot using serial dilutions of sodium nitrite [21].

\section{Estimation of serum hydrogen sulphide $\left(\mathrm{H}_{2} \mathrm{~S}\right)$ level}

For $\mathrm{H}_{2} \mathrm{~S}$ estimation, $500 \mu \mathrm{l}$ of tissue supernatant and $75 \mu \mathrm{l}$ of serum sample was added to the premixed zinc acetate $(1 \% \mathrm{w} / \mathrm{v})$ solution, respectively. The concentration of $\mathrm{H}_{2} \mathrm{~S}$ in the serum sample was measured using the method elaborated by us previously. The absorbance was read spectrophotometrically at $670 \mathrm{~nm}$ [22].

Cyclooxygenase (COX) and lipoxygenase (LOX) estimation The COX and LOX were estimated in the rat serum sample followed by the method elaborated elsewhere [23].

\section{Caspase 3 and caspase8 estimation}

96-well amber colored plate has been used for the colorimetric identification of caspase-3/8. The estimation was performed on the basis of methodology elaborated by us previously [24].

\section{Gas chromatographic (GC) analysis of mammary gland tissue}

The fatty acid methyl esters (FAME) analysis was performed for the estimation of free fatty acids in the mammary gland tissue. The methodology of FAME was elaborated elsewhere [25].

\section{Western blotting}

The mammary gland tissue sample was homogenized using RIPA lysis buffer, isolated by acetone precipitation and total protein concentration was assayed by using Bradford method [26]. All the protein samples were resolved on SDS-PAGE gels with Tris buffer system. The proteins were transferred to PVDF membrane by electroblotting by semidry system. Prestained protein ladder was used as a molecular weight identification marker. After $2 \mathrm{~h}$ of blocking with blocking buffer at room temperature, membranes were processed for primary antibody binding (1: 2000 dilutions) against Bcl-xl (MA5-15,142), BAD (SC-8044), NFKBp65 (MA5-1616), UCHL-1 (MA1-83428) and COX (MA5-14568) in $4{ }^{\circ} \mathrm{C}$ followed by respective secondary antibody (anti-rabbit (SC-2030), anti-goat (SC-2020) and anti-mouse (31,430, Pierce Thermo Scientific, USA) in 1:5000 dilutions. $\beta$ actin (MA5-15739-HRP) was used as loading control. The PVDF blotting membranes were processed at final steps by using an enhanced ECL substrate (Western Bright ECL HRP substrate, Advansta, Melanopark, California, US) in Geldock system. The proteins bands were quantified using ImageJ software [27].

\section{Digital image analysis}

For microscopic analysis data obtained from $H \& E$ and SEM micrographs, six randomly chosen regions were selected from all group and analysed independently for each respective sample. To identify the luminescence from experimental images and convert them into the heights to the final surface plot,3D interactive surface plot experiments was used to identify the pure $H \& E$ stained and SEM areas nearest neighbouring sampling in a square plot. This unmixing ultimately helps to distinguish between nuclear, ECM and background stains in a single complimentary image. Automated score was assigned by observing and measuring the pure $H \& E$ staining pattern and SEM micrograph in Image J standard program feature.

\section{Protein-protein interaction and gene ontological studies}

To identify the various functional relations between different gene and protein protein-protein interactions were studied using STRING 10.0. Different biological process, cellular component and biological functions has been identified by gene ontological study (Search tool 
for the Retrieval of Interacting Genes/Proteins) software (http://string-db.org).

\section{Statistical analysis}

All data were presented as mean \pm SD and analyzed by one way ANOVA followed by Bonferroni's multiple comparison tests for the possible significance identification between the various groups $" p<0.05,{ }^{* *} p<0.01$, ${ }^{* * * * *} p<0.001$ were considered statistically significant. Statistical analysis was carried out using Graph Pad Prism (5.01), San Diego, California.

\section{Results}

\section{Effect of Tadalafil upon hemodynamic changes}

Heart rate variability (HRV) is the noninvasive measures of autonomic nervous system (ANS) regulation. It was previously reported that altered and dysfunctional ANS has been reported cancer patients. The RR interval was elevated in MNU treated group $(0.18 \pm 0.02)$ and Tadalafil in low dose $(2 \mathrm{mg} / \mathrm{kg}$, p.o.) restored RR interval about to normal $(0.16 \pm 0.01)$. On the other hand, heart rate (HR) was increased in MNU treated group (331.95 \pm 0.68) which was diminished after Tadalafil treatment in dose dependent manner. QT interval was considerably declined in toxic control group $(0.05 \pm 0.01)$ which was restored after Tadalafil treatment $(0.06 \pm 0.01)$ (Fig. 1).

In accordance with HRV parameters, the frequency domain parameters like average RR, median RR, SDRR and SD rate were elevated after MNU treatment. Tadalafil treatment helped to restore the above said parameters about to normal (Fig. 2).

\section{Morphological analysis of rat mammary gland tissue Carmine staining}

The two main markers for angiogenesis are alveolar bud (ABs) count and differentiation (DF) score. In carmine staining, the no. of $A B s$ and $D F$ score were calculated. The $\mathrm{ABs}$ (both $\mathrm{AB} 1$ and $\mathrm{AB} 2$ ), lobules and $\mathrm{DF}$ were elevated after MNU treatment $(17 \pm 5.65,12 \pm 5.65,12 \pm 2.82$ and $41 \pm 14.12)$ and after Tadalafil treatment; all the parameters of cell proliferation were restored to normal (Fig. 3a-d).

\section{H\&E staining}

$H \& E$ staining provide the cellular and morphological alterations occur in the tissue. In normal control tissues, all the cell organelles were clearly visible (Fig. 4a). MNU treatment was evident in scattered pattern of cuboidal epithelial cells (CEC), myoepithelial cells (MEC), lymphocytes, adipocytes

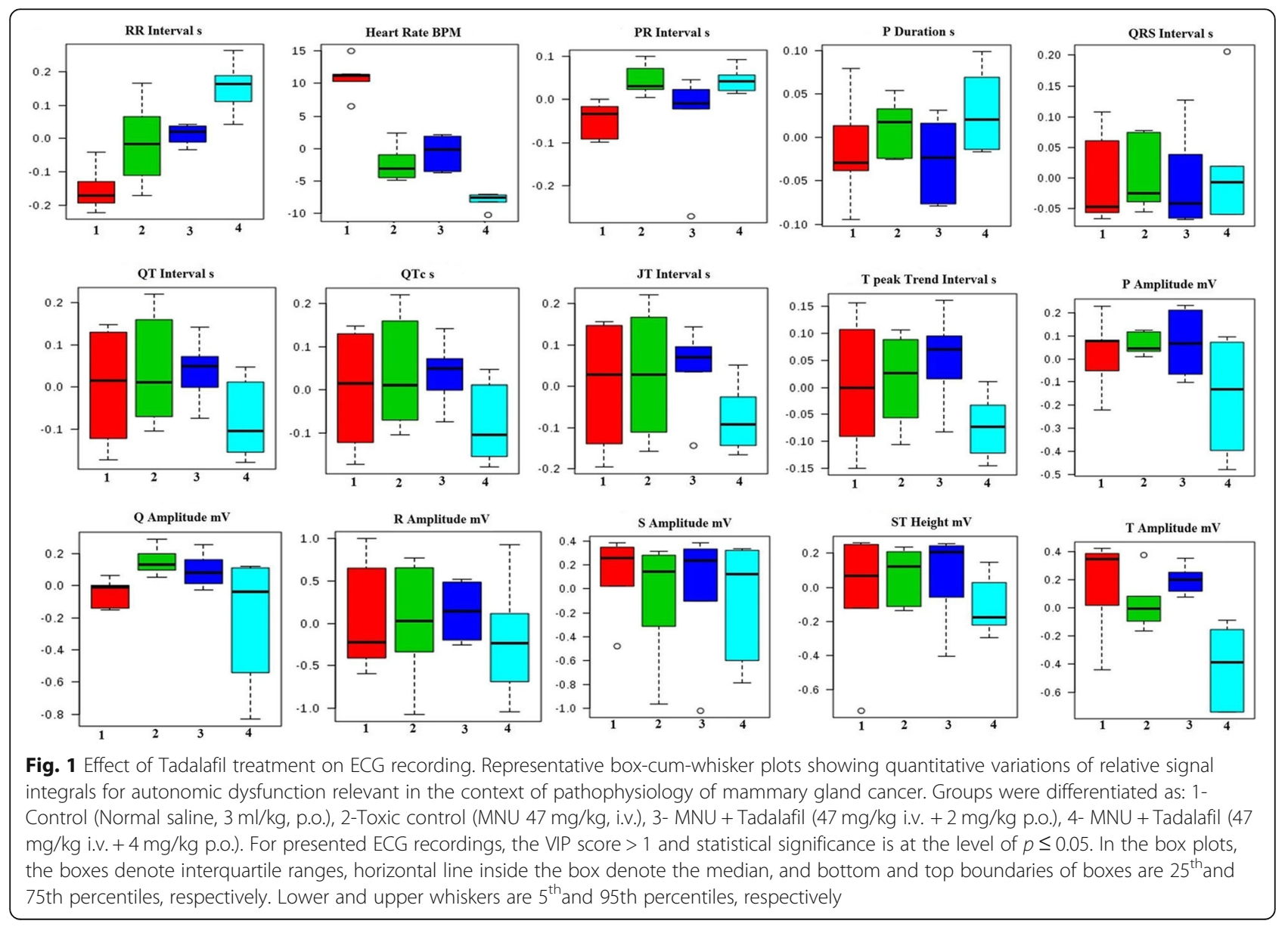



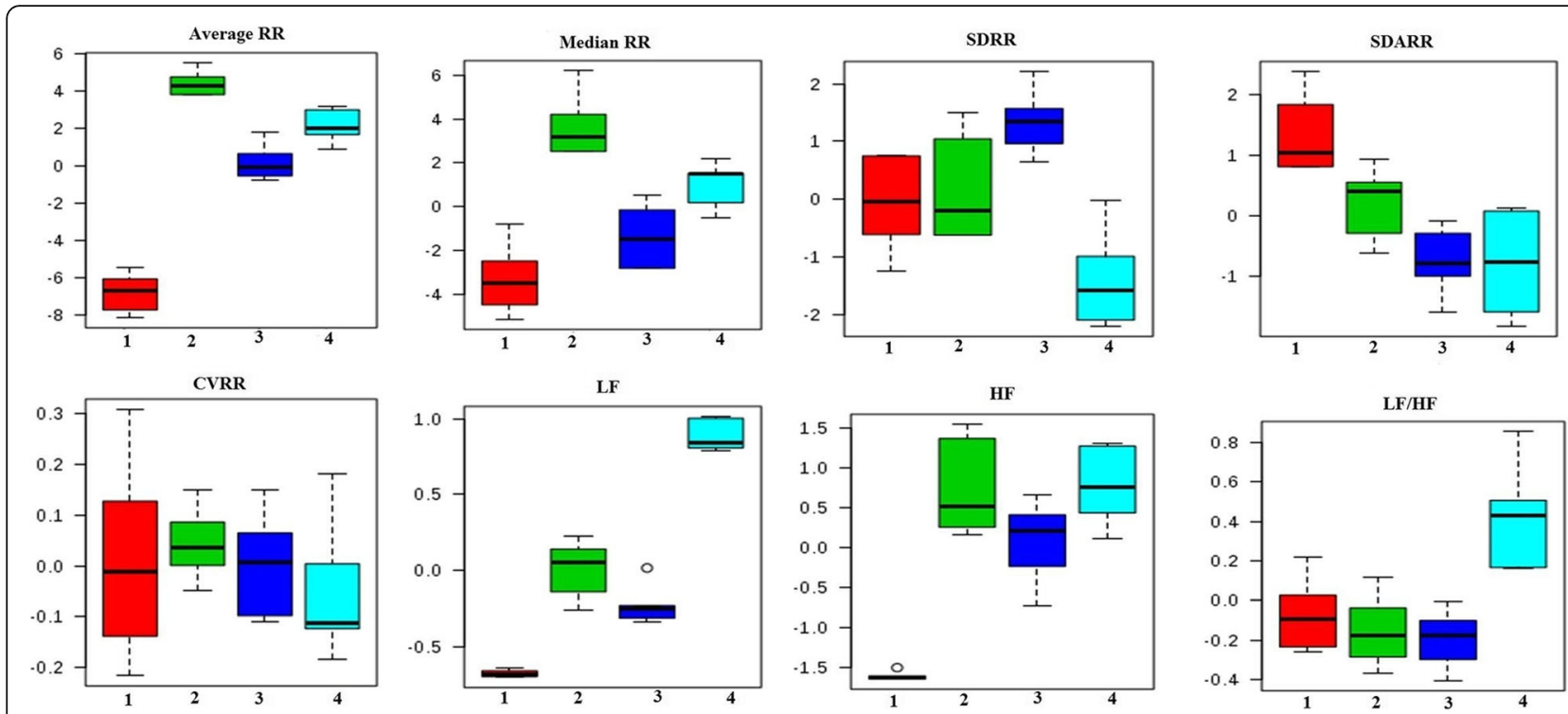

Fig. 2 Effects of Tadalafil treatment on HRV. Representative box-cum-whisker plots showing quantitative variations of relative signal integrals for HRV parameters relevant in the context of pathophysiology of mammary gland cancer. Groups were differentiated as: 1-Control (Normal saline, 3 $\mathrm{ml} / \mathrm{kg}$, p.o.), 2-Toxic control (MNU $47 \mathrm{mg} / \mathrm{kg}$, i.v.), 3- MNU + Tadalafil ( $47 \mathrm{mg} / \mathrm{kg}$ i.v. $+2 \mathrm{mg} / \mathrm{kg}$ p.o.), $4-\mathrm{MNU}+$ Tadalafil (47 mg/kg i.v. $+4 \mathrm{mg} / \mathrm{kg}$ p.o.). For presented heart rate variability, the VIP score $>1$ and statistical significance is at the level of $p \leq 0.05$. In the box plots, the boxes denote interquartile ranges, horizontal line inside the box denote the median, and bottom and top boundaries of boxes are $25^{\text {th }}$ and 75 th percentiles, respectively. Lower and upper whiskers are $5^{\text {th }}$ and 95 th percentiles, respectively

and duct along with loose connective tissue (LCT) and dense connective tissues (DCT) (Fig. 4b). Tadalafil treatment restored all the parameters in dose dependent manner (Fig. 4c and d).

\section{SEM analysis}

SEM analysis was used to analyse the internal surface of whole cells and its organelles. In normal control tissue, collagen layer, duct and intra-arterial cushion/collagenous covering, were seen clearly (Fig. 5a). All the cellular organelles were absent in MNU treated group (Fig. 5b). Tadalafil treatment perceived decrease in tumor microvessel formation with restoration of intra-arterial cushion (Fig. 5c and d).

\section{Effect of antioxidant markers upon mammary gland carcinoma}

Reactive oxygen species (ROS) are the byproducts of normal metabolism through the electron transport chain. ROS and other oxidative stress are considered as a driving force for cancer progression. Tadalafil treatment helps to restore the diminished antioxidant profile, when compared with MNU treated toxic group. The phenomena of protein and lipid peroxidation were very well evident after MNU treatment which correlates with the high level of TBARs and PC after MNU treatment $(872.12 \pm 72.98 \mathrm{nM}$ of $\mathrm{MDA} / \mu \mathrm{g}$ of protein and 12.24 \pm $1.79 \mathrm{nM} / \mathrm{ml}$ respectively). Tadalafil treatment decreased the level of TBARs and PC in dose dependent manner
$(499.79 \pm 109.2298 \mathrm{nM}$ of $\mathrm{MDA} / \mu \mathrm{g}$ of protein and $7.28 \pm 0.82 \mathrm{nM} / \mathrm{ml})$. GSH level in MNU treated group $(0.61 \pm 0.04 \mathrm{mg} \%)$ was restored to almost control group after Tadalafil treatment $(1.39 \pm 0.10 \mathrm{mg} \%)$. The level of SOD and catalase was increased after MNU treatment $(0.33 \pm 0.07$ units of SOD/mg of protein and $2.46 \pm 0.48$ $\mathrm{nM}$ of $\mathrm{H}_{2} \mathrm{O}_{2} / \mathrm{min} / \mathrm{mg}$ of protein) which was decreased after Tadalafil treatment to a significant level (i.e. $0.17 \pm$ 0.13 units of SOD and $1.43 \pm 0.01 \mathrm{nM}$ of $\mathrm{H}_{2} \mathrm{O}_{2}$ ) (Fig. 6).

\section{Effect of inflammatory markers upon mammary gland carcinoma}

Inflammatory markers produced reactive nitrogen species (RNS) and ROS from epithelial and inflammatory cells, which leads to DNA damage. The inflammatory markers $\left(\mathrm{NO}, \mathrm{H}_{2} \mathrm{~S}, \mathrm{COX}\right.$ and $\left.\mathrm{LOX}\right)$ were upregulated after MNU treatment. After Tadalafil treatment, the level of all the inflammatory markers was downregulated (Fig. 7).

\section{Effect of Tadalafil upon caspase assay}

Caspases cysteinyl protease family members and they play a crucial role in apoptosis. The serum caspase 3 and caspase 8 was measured using fluorometric assay kits. The caspase 3 and caspase 8 levels were decreased in MNU treated group and after Tadalafil treatment, the levels of casapse 3 and caspase 8 were upregulated in a dose dependent manner (Fig. 7). 


\section{a) Carmine staining of whole mount mammary gland tissue}
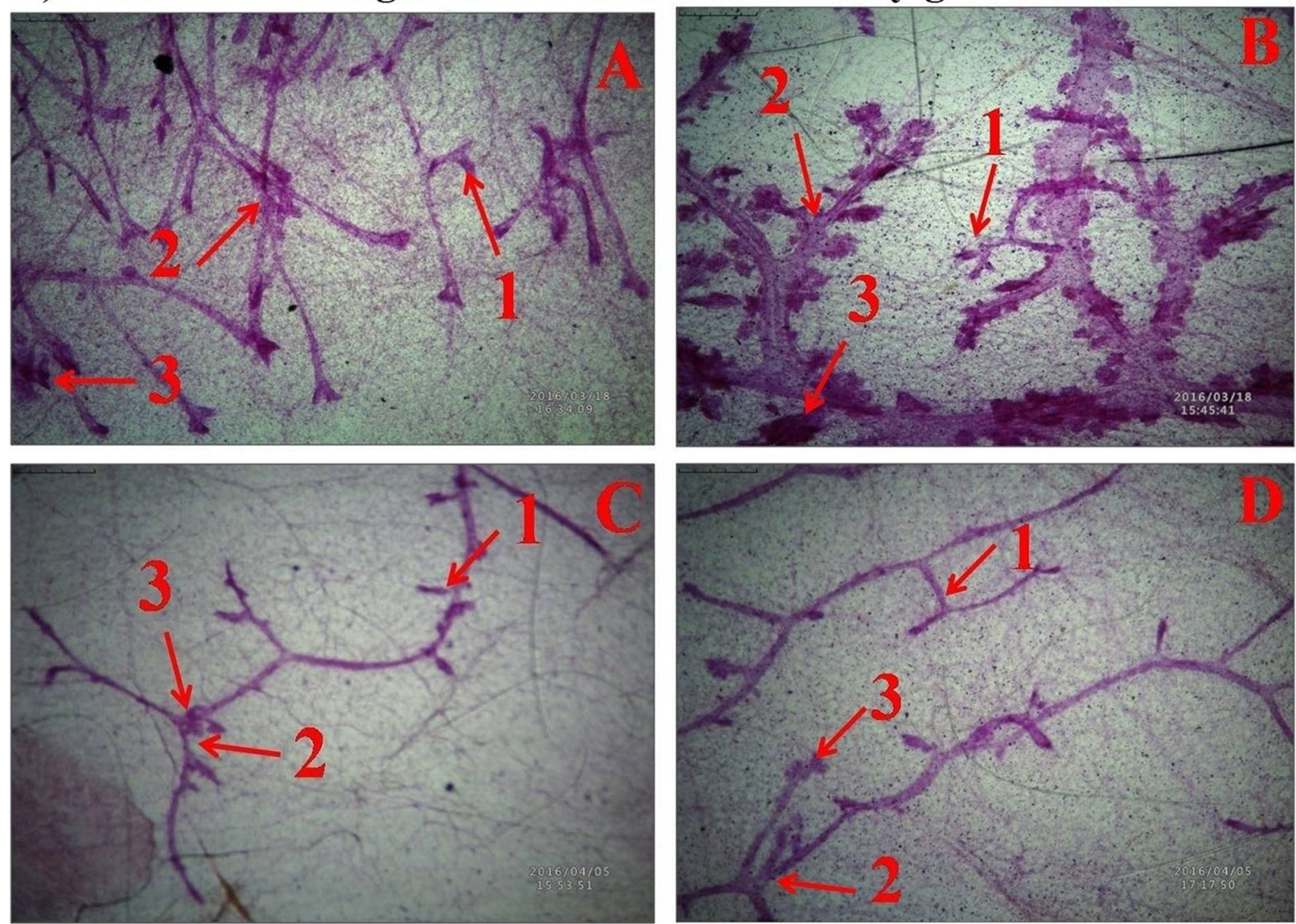

b) Alveolar bud, lobules and differentiation score count

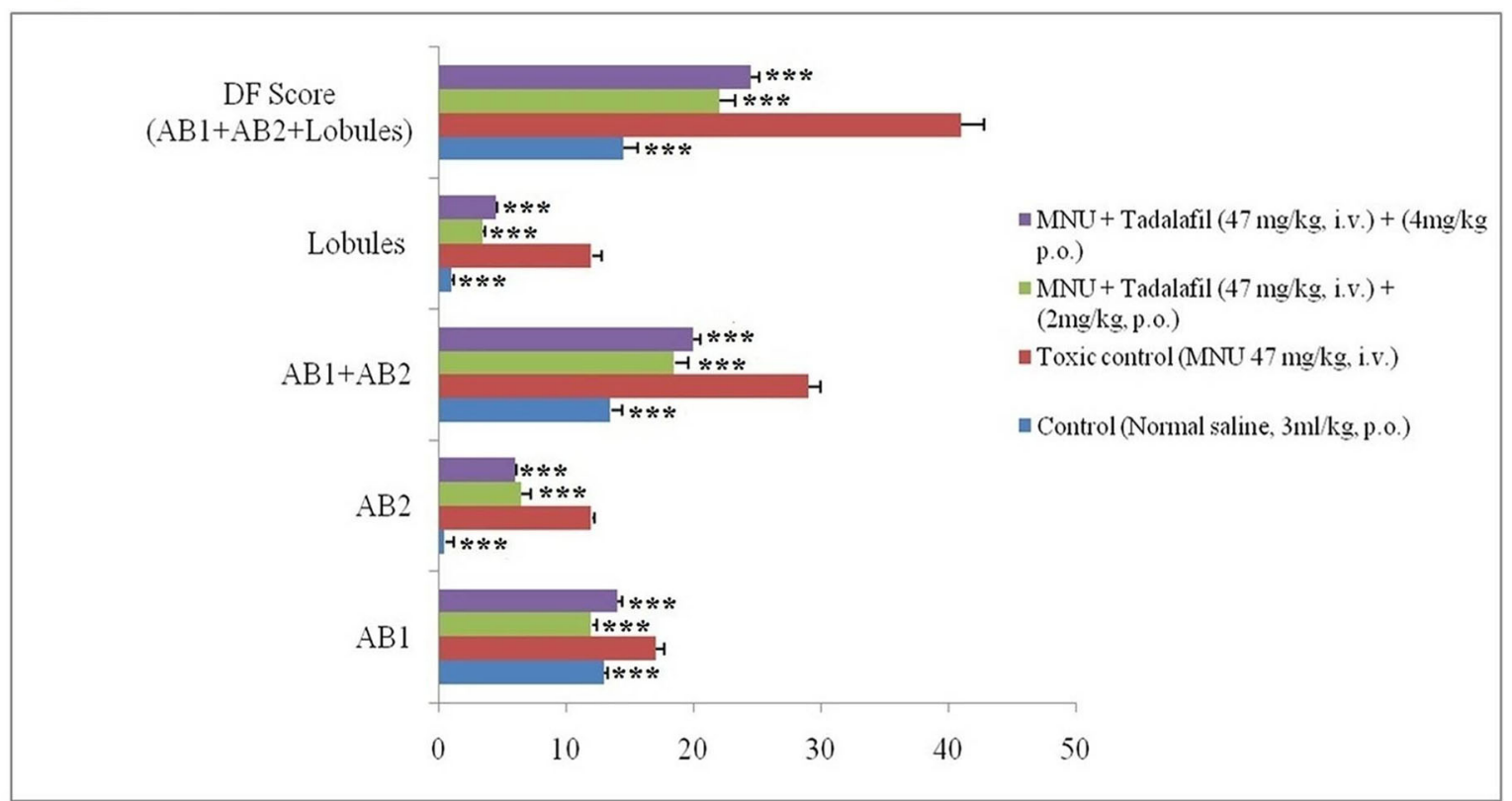

Fig. 3 (See legend on next page.) 
(See figure on previous page.)

Fig. 3 Carmine staining of mammary gland whole mount tissue. Whole mount carmine alum staining of ductal epithelium reveals the presence of $A B 1$ (1), AB2 (2) and lobules (3) in respective groups [a-control (normal saline, $3 \mathrm{ml} / \mathrm{kg}$, p.o.); b-toxic control (MNU $47 \mathrm{mg} / \mathrm{kg}$, i.v.); c (MNU + Tadalafil; $47 \mathrm{mg} / \mathrm{kg}$ i.v. $+2 \mathrm{mg} / \mathrm{kg}$ p.o.) and $\mathbf{d}$ (MNU + Tadalafil; $47 \mathrm{mg} / \mathrm{kg}$ i.v. $+4 \mathrm{mg} / \mathrm{kg}$ p.o.)]. The extent of AB and lobules formation is excessive in the toxic group (b) which was subsided after Tadalafil treatment $(\mathbf{c} \& \mathbf{d})$. The extent of AB and lobules formation is excessive in the toxic group (b) which has been subsided with respective treatment groups $(\mathbf{c} \& \mathbf{d})$. The ABs score, lobules and DF scores were also higher in toxic control which was subsided after Tadalafil treatment in a dose dependent manner

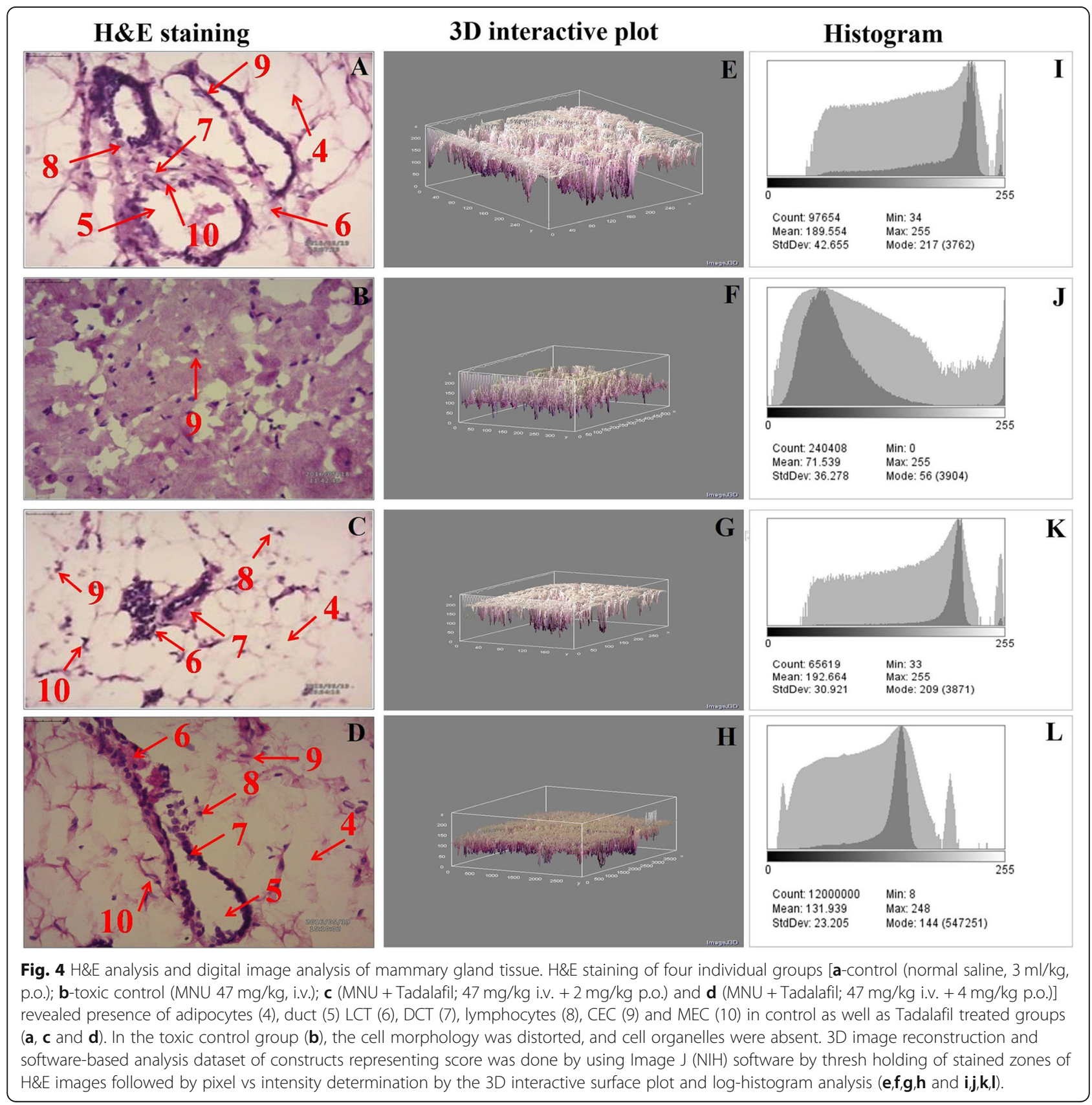




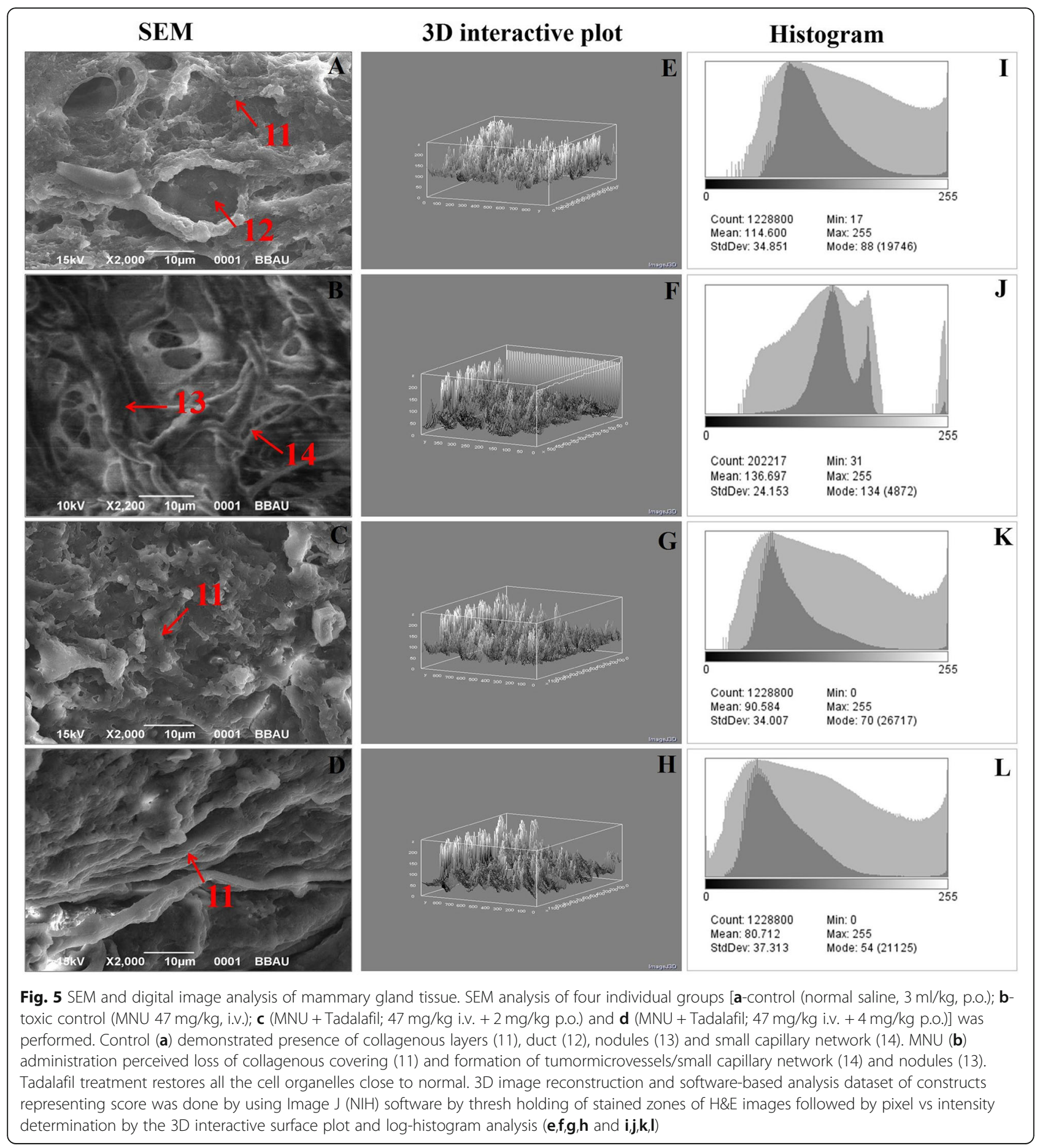

\section{Effect of Tadalafil upon FAME analysis}

FAME assay converts cellular lipids into fatty acid methyl esters, resolved and identified by gas chromatography. After MNU treatment, there was substantial increase in saturated fatty acid, monounsaturated fatty acid along with decrease in the unsaturated fatty acid and polyunsaturated fatty acid content. Tadalafil treatment restored the lipid content in
MNU treated animals (Additional file 1: Figure S1 and Additional file 2: Table S1).

\section{Immunoblotting analysis}

Western blotting is used to separate and identify proteins. In this technique a mixture of proteins is separated on the basis of molecular weight through gel electrophoresis. Bclxl (anti-apoptotic) expression was increased after MNU 


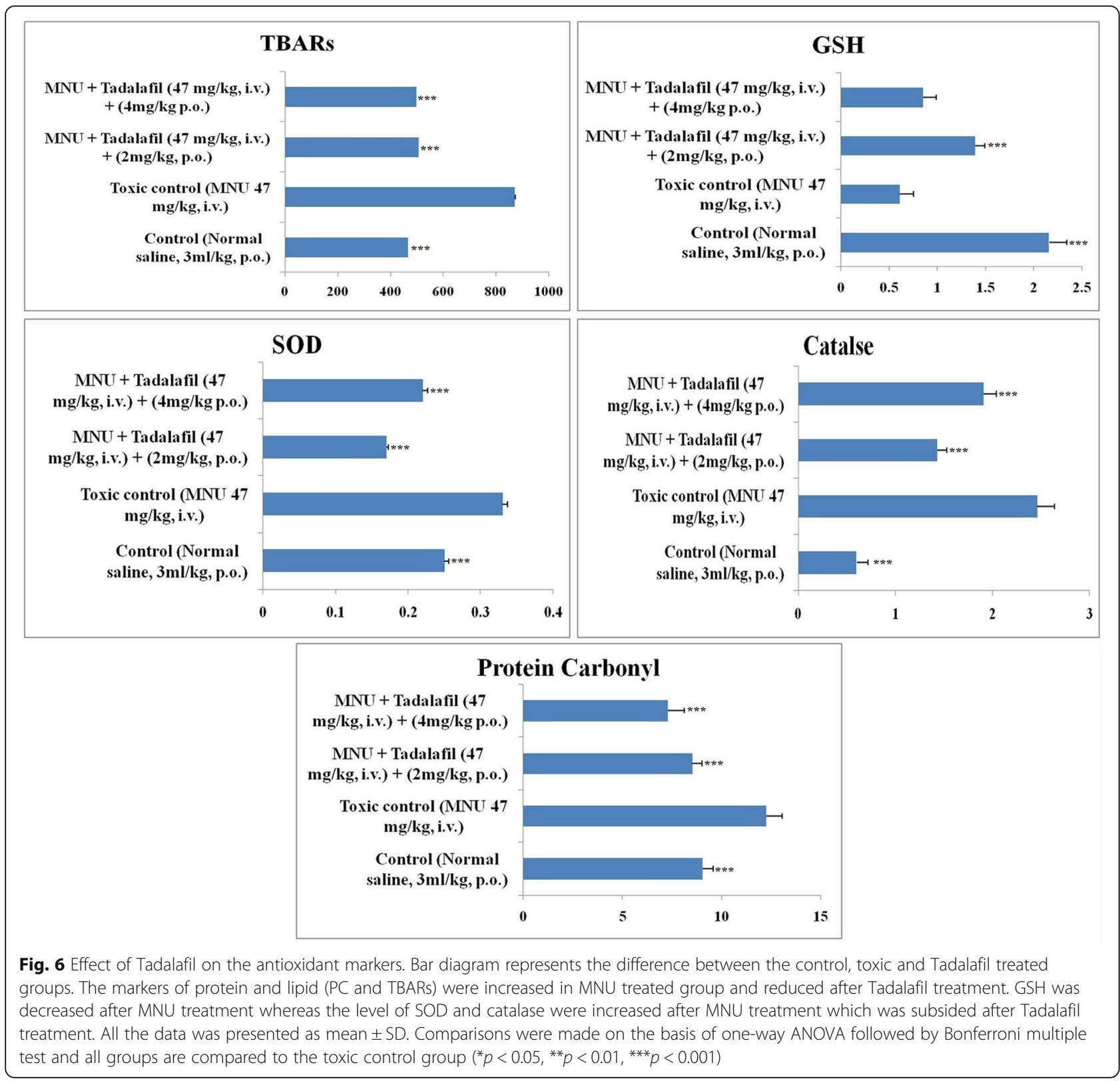

treatment with diminished level of BAD (proapoptotic). Tadalafil treatment helped to restore the same and suggesting mitochondrial dysfunction (Fig. 8). MNU treatment validates the inflammation when perceived through increased expression of COX, NFKBp65 and UCHL-1. Tadalafil treatment dose-dependently curtails down the expression of COX, NFkBp65 and UCHL-1(Fig. 8).

\section{Discussion}

Despite vast development in the cumulative survival rate of hormone dependent breast cancer patients but postoperative or chemotherapy received advanced metastatic stage still a positive life-threatening for cancer patient. Most primitive challenges in mammary gland carcinoma are to target different key proteomic marker that plays a crucial role in downstream pathways of carcinogenesis and distinct tissue metastasis. Thus it will be worthy to identify the proteomic check point for the development of innovative and safe therapeutic outcome to control and curing of malignancy. The present study demonstrated the repurposing effect of the PDE- 5 inhibitor (Tadalafil) upon MNU induced mammary gland carcinoma in albino wistar rats. MNU is one of the classical laboratory carcinogens of alkyl-nitrosourea family which has the ability to directly alkylate DNA [28]. MNU is a widely used chemical carcinogenic model for induction of mammary gland carcinoma in albino wistar rats [14]. Cumulative cardiotoxicity and autonomic dysfunction is 


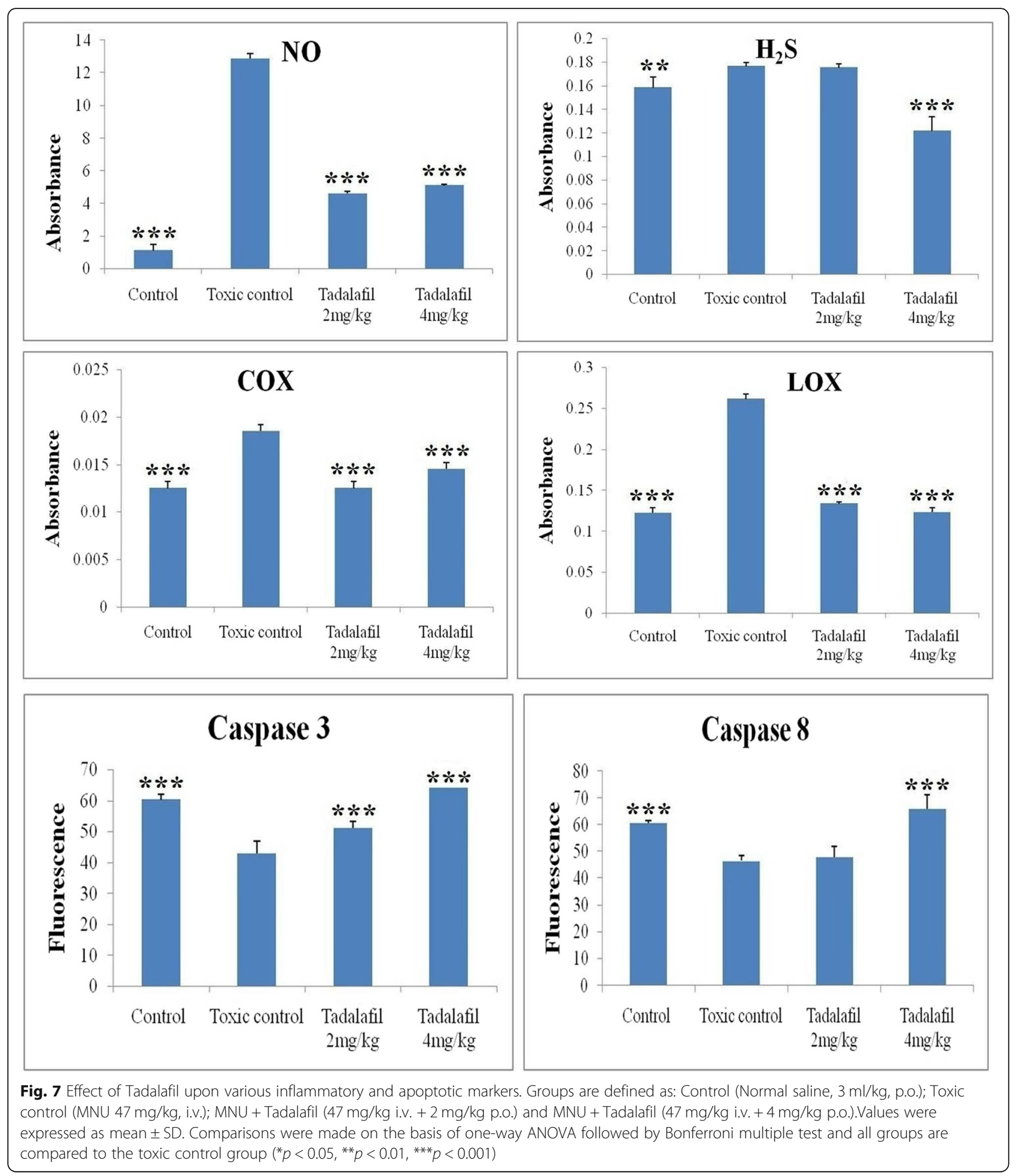

a well evident side effect of long term chemotherapy regimen of cancer patients [29]. It ultimately hinders the application of so many potent active chemotherapeutic agents. Being evidently well effective in pulmonary arterial hypertension, pulmonary vasodilatation, cardiac remodelling, diastolic function, interstitial fibrosis and inflammation, coronary microcirculation it was an urgent need to evaluate the cardiological parameter during the study and report safety of Tadalafil dose used throughout the study. Reduced HRV constitutes an independent prognostic factor for autonomic dysfunction. It was previously reported that HR was increased in breast 


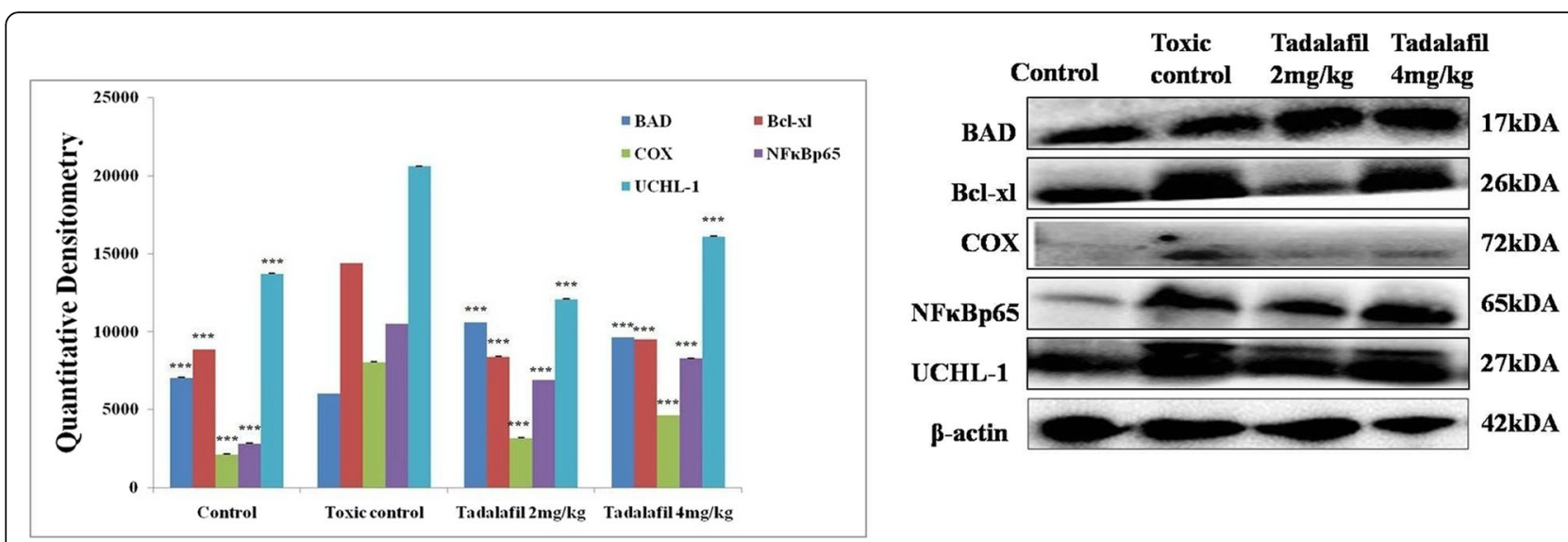

Fig. 8 Tadalafil mediated activation of mitochondrial mediated apoptosis pathway. Protein extracted from individual groups [Control (Normal saline, $3 \mathrm{ml} / \mathrm{kg}$, p.o.); Toxic control (MNU $47 \mathrm{mg} / \mathrm{kg}$, i.v.); MNU + Tadalafil ( $47 \mathrm{mg} / \mathrm{kg}$ i.v. $+2 \mathrm{mg} / \mathrm{kg}$ p.o.) and MNU + Tadalafil $(47 \mathrm{mg} / \mathrm{kg}$ i.v. $+4 \mathrm{mg} /$ kg p.o.)] were subjected to immunoblotting of proapoptotic (BAD) and anti-apoptotic (Bcl-xl) marker along with COX, NFKBp65 and UCHL-1. $\beta$ actin was used as internal loading control. Each experiment was performed in triplicate. The data was represented as mean \pm SD. The groups were significantly different by one-way ANOVA followed by Bonferroni multiple tests. All groups were compared to the toxic control group $\left({ }^{*} p<0.05,{ }^{* *} p<0.01,{ }^{* * *} p<0.001\right)$

cancer patients [30].RR interval, $\mathrm{R}$ waves and $\mathrm{HR}$ are the parameters which represent autonomic dysfunction. In the present study, the RR interval, $R$ waves and HR were increased in MNU treated group which was decreased after Tadalafil treatment (Fig. 1). In the time domain, we analysed average RR, median RR, SDRR, CVRR and SD rate. All the cardiological parameters were significantly increased in MNU treated group and Tadalafil treatment helps normalised it. The reason to follow the main spectral components of LF is to analyse the frequency domain and measure sympathetic and parasympathetic activities. On the other hand, vagal parasympathetic activity and LF/HF ratio which indicates the sympathovagal balance also examined. In MNU treated group; LF, HF and LF/HF were increased which were subsided after Tadalafil treatment (Fig. 2). In summary, PDE-5 inhibitor selectively exhibit pleiotropic actions through pulmonary vasodilatation, LV remodelling, improved diastolic function, negative inotropic effects in naive cardiac myocytes, antiarrhythmic properties which ensure its long term safety in chemotherapeutic regimen.

The anti-carcinogenic activity of Tadalafil was again evaluated on the grounds of morphological architecture using carmine staining, H\&E staining and SEM analysis. The results of carmine staining were in line with the previous reported results [14]. Increased ABs, lobules and DF score is the sign for cellular proliferation and the same was reported in MNU treated group [27]. The number of ABs, lobules and DF score were decreased after Tadalafil treatment in dose dependent manner (Fig. 3a-d). Histopathogical analysis of control group revealed the presence of $\mathrm{CEC}, \mathrm{MEC}$, lymphocytes, adipocytes, duct, LCT and DCT. All the cell organelles were distorted after MNU treatment, LCT and DCT were hard to identify. After Tadalafil treatment, all the cell organelles were restored in dose dependent manner (Fig. 4a-d). Mammary gland tissues were also evaluated for its surface texture analysis using SEM. After MNU treatment, marked proliferation was observed with increased in micro vessel formation, loss of intra-arterial cushion and vascular conglomeration. Tadalafil treatment restored the cellular architecture after SEM analysis (Fig. 5a-d). The finding from the morphological analysis revealed that Tadalafil in dose dependent manner restored the features of cellular proliferation and warrants its role as an anti-carcinogenic drug.

Oxidative stress is a well-known fact in cancer progression. It is defined as a physiological state in which the level of ROS is higher and generation of free radical is occurred. In mitochondria of the cell, ROS is generated through adenosine triphosphate (ATP) where electrons react with oxygen $\left(\mathrm{O}_{2}\right)$ and results in the formation of superoxide anion $\left(\mathrm{O}_{2}{ }^{\circ}\right)$ [31]. Downstream experimental condition reveals high level of NO in toxic group which may be endogenous $\mathrm{NO}$ which inhibited cytochrome c oxidase, causing generation of excess ROS. Previous studies validated that oxidative stress is linked with many of the pathophysiological diseases. Oxidative stress leads to damaging of the DNA molecule and regulates the progression of many cancers [32]. The markers of oxidative stress are TBARs, PC, SOD, catalase and GSH. In the present study, protein markers (TBARs and PC) were increased after MNU treatment and these markers decreased after Tadalafil treatment in dose dependent manner (Fig. 6). The level of GSH was decreased in MNU treated group which was restored after 
Tadalafil treatment. SOD and catalase are the major component of antioxidant defence system and the level of SOD and catalase was increased after MNU treatment which was normalised after Tadalafil treatment (Fig. 6).

Inflammatory markers also have a profound effect upon cancer prognosis. Tadalafil is a well-known specific inhibitor of the NO/cGMP pathway which has been perceived by NO [33]. Significant downregulation has been observed in the treatment groups which revealed Tadalafil mediated inhibition of NO synthesis in tissue and inhibition of intracellular ROS generation [34]. Overexpression of cystathionine-gamma-lyase (CSE), acystathionine-betasynthase (CBS), and 3-mercaptopyruvate sulfurtransferase (3-MST) which ultimately leads to increased amounts of $\mathrm{H}_{2} \mathrm{~S}$, which augmented tumour growth and distinct metastasis by activating cellular bioenergetics, proliferative, migratory, and invasive signalling pathways [35]. Involvement of $\mathrm{NO}-\mathrm{H}_{2} \mathrm{~S}$ dual signalling is responsible for the curtailment of $\mathrm{ABC}$ transported mediated drug resistance and inhibition of carcinogenesis via c-GMP blockade [36]. Tadalafil treatment downregulates the level of $\mathrm{NO}$ and $\mathrm{H}_{2} \mathrm{~S}$ in MNU treated animals (Fig. 7).

Dual inhibition strategies for COX and LOX in cancer are one of the established areas of research and our laboratory is very much focused in the specific area of interest. Previously, we have shown that dual inhibition (specific combinations of COX and LOX metabolites) has been considered for future best possible chemotherapeutic regime [24]. Tadalafil treated group shows the reduction of COX and LOX when examined through biochemical and immunoblotting assay in comparison with MNU treated group. Several research reports suggested that the expression of COX is associated with incidence of breast cancer. It includes large tumour size, positive axillary lymph node metastasis and HER2positive tumour status [37]. Previous study on mice and rats that moderate to high $\mathrm{COX}$ expression is related to generation of mammary gland tumours. The result of present study also indicates the same (Fig. 7). The expression of COX in MNU treated group was increased which was subsided after Tadalafil treatment. Modulation of downstream metabolite like PGE2, TXA2 and TXB2 and LTA4, LTB4, LTC4, LTD4, LTE4 can exploit multidirectional signalling cascade to exert their anticancer effects and the same have been explored in the present study with wider prospects to enlighten the chemotherapeutic strategies by repurposing the mechanism of PDE-5 inhibitor. Dual inhibition ensures the alteration of AA metabolism in cancer cells and exhibits subsided inflammation, cell proliferation and neo-angiogenesis. Identification of specific subtype of COX and LOX responsible for apotogenic potential of Tadalafil is the future direction of our research [38].
To establish possible mechanisms of the anticancer effects via PDE-5 inhibition and role in caspase-dependent apoptosis and cell growth arrest we have checked the caspase group of protein. Caspase 3 and caspase 8 are key regulators of the apoptotic response in which caspase 3 is executioner caspase and caspase 8 is initiator caspase. Caspase 8 is activated through self-cleavage and after that it activates downstream effector caspase like caspase 3 which [39] may be linked to concomitant increases in regulation of downstream pathways through JNK, mitogen-activated protein kinase 1 , decreased Wnt/ $\beta$-catenin expression and down-regulation of cyclin D, inhibition kinases $1 / 2$ (ERK1/2) and alterations in the regulation of $\mathrm{p} 42 / \mathrm{p} 44$ (MAPK) and $\mathrm{p} 21$ pathways. In the present study, the results from caspase assay revealed that after MNU treatment the level of caspase 3 and 8 was decreased and the same was restored after Tadalafil treatment (Fig. 7).

FAME analysis revealed the participation of saturated fatty acids, monounsaturated fatty acid, unsaturated fatty acid and polyunsaturated fatty acids. It was reported that women's consumed saturated fatty acid in diet have a higher risk of breast cancer and the same observations were found in the present study [40]. The sharp peaks of saturated fatty acid were seen in MNU group which was subsided after Tadalafil treatment. Monounsaturated fatty acid has both effects depending upon the source of food. In MNU treated group, the level of monounsaturated fatty was increased and the same was decreased after Tadalafil treatment. It was previously reported that unsaturated Trans fatty acid may increase the risk of invasive breast cancer and the same observations were found in FAME analysis after MNU treatment [41]. Various research reports validated the promoting as well as inhibitory effect of polyunsaturated fatty acid and mammary gland tumorigenesis [41]. In the resent piece of work, inhibitory effects of polyunsaturated fatty acids were seen after Tadalafil treatment (Additional file 1: Figure S1 and Additional file 2: Table S1).

Cell apoptosis is a process of programmed cell death and it is regulated by two major pathways: intrinsic and extrinsic pathways. The intrinsic pathway and Mitochondrial Outer Membrane Permeabilization (MOMP) are regulated through the balance of pro- and anti-apoptotic proteins of Bcl-2 family [42, 43]. In the present study, the expression of anti-apoptotic protein $(\mathrm{Bcl}-\mathrm{xl})$ was increased after MNU treatment and the vice versa effect was found upon pro-apoptotic protein (BAD). Collaborative result from pro-apoptotic and anti-apoptotic protein with downstream caspase cascade validate the participation of Tadalafil in mitochondrial mediated death apoptosis pathway (Figs. 8 and 9).

Previous reports revealed that the $26 \mathrm{~S}$ centre of UCHL-1 is regulated by $20 \mathrm{~S}$ immunoproteasome subunit 


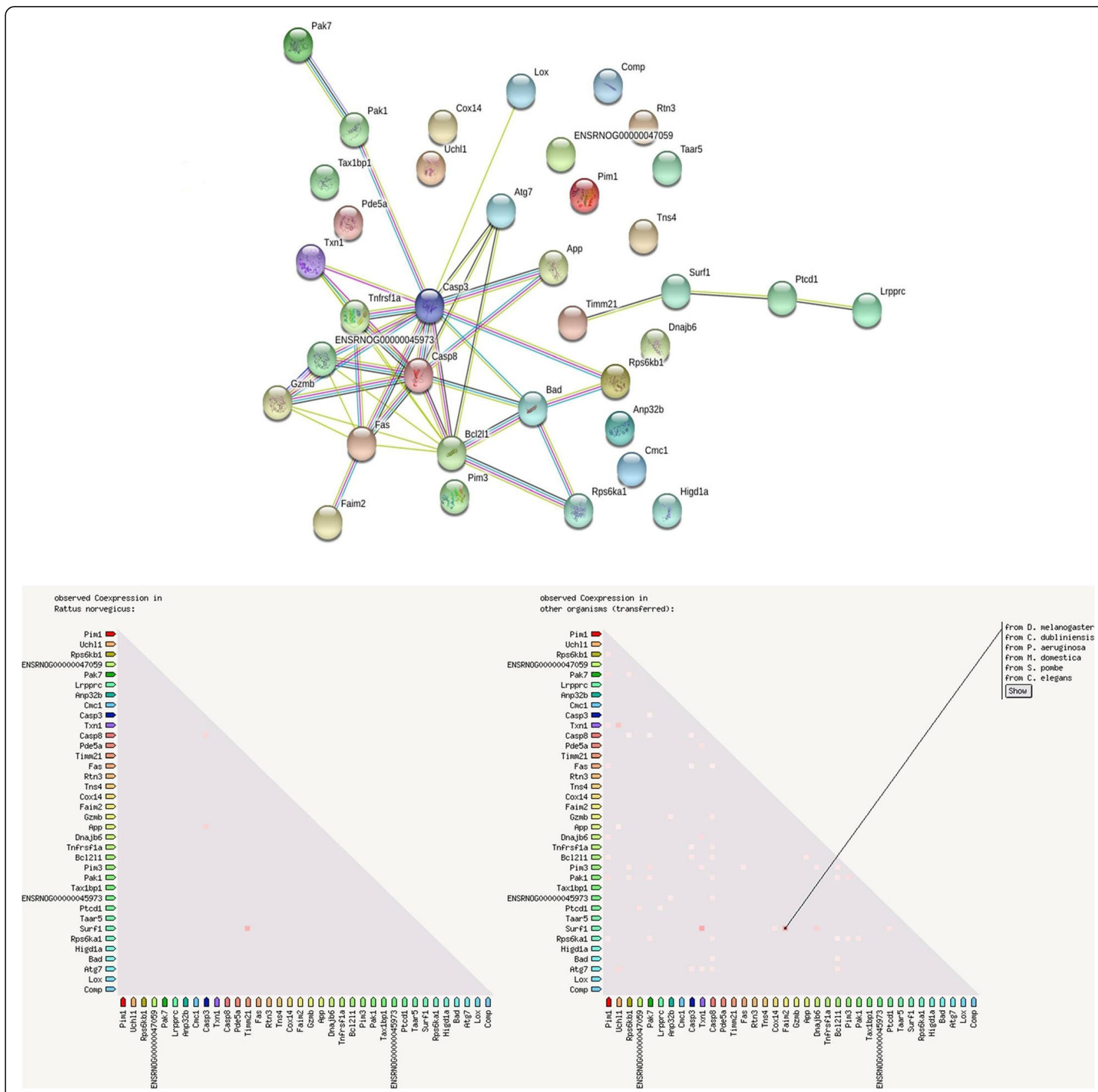

Fig. 9 Protein-Protein interaction and Co-expression network analysis. Protein-protein interaction and co-expression analysis was performed using STRING V 10.0 with respect to differentially expressed proteins as identified from the Western blot analysis in relation to mitochondrial and hypoxic proteomic checkpoints

which inhibits the degradation of the ubiquitinated proteins [21]. In MNU treated group the expression of UCHL-1 was increased which was subsided after Tadalafil treatment. The same relation has been linked with the expression of $\mathrm{NF} \kappa \mathrm{B} / \mathrm{p} 50$ precursor $\mathrm{p} 105$ and $\mathrm{I} \kappa \mathrm{B} \alpha$ as it is essential for activity of NFKBp65. In line with to above results, the expression of NFkBp65 was increased in MNU treated group which was decreased after Tadalafil treatment (Figs. 8 and 9).

\section{Conclusion}

Authors would like to conclude that PDE-5 inhibitor (Tadalafil) had a marked effect upon MNU induced mammary gland cancer. The mechanism of action of Tadalafil is validated through mitochondria mediated death apoptosis pathway and Tadalafil also decreased the inflammatory markers. Earlier, it was also reported that combination of sildenafil with celecoxib was found to be cytotoxic in breast, hepatoma, colorectal cancer, 
glioblastoma and medulloblastoma cell lines. It would be helpful if well directed future preclinical and clinical study targeting the repurposing effect of PDE5 inhibitor, to explore its additional mechanism. Tadalafil has lowcost and low-toxicity with great preclinical potential which can be further explored through well directed clinical trial in near future to include it with current and emerging standard of care treatments in breast cancer.

\section{Supplementary information}

Supplementary information accompanies this paper at https://doi.org/10. 1186/s12885-019-6152-9.

Additional file 1: Figure S1. FAME analysis of the mammary gland tissue subjected to MNU and Tadalafil.

Additional file 2: Table S1. Fatty acid profiling of mammary gland tissue treated with MNU and Tadalafil.

\section{Abbreviations}

3-MST: 3-mercaptopyruvate sulfurtransferase; AA: Arachidonic acid; ABs: Alveolar buds; ATP: Adinosine triphosphate; BSA: Bovine serum albumin; CAMP: Cyclic adenosine monophosphate; cGMP: Cyclic guanosine monophosphate; CBS: Acystathionine-beta-synthase; CEC: Cuboidal epithelial cell; COX: Cycloxygenase; CSE: Cystathionine-gamma-lyase; DCT: Dense connective tissue; DF: Differentiation score; DTT: Dithiothreitol; ECG: Electrocardiogram; ERK: Extracellular-signal regulated kinases; FAME: Fatty acid methyl esters; FTC: Ferrithiocyanate; GSH: Glutathione; H\&E: Hematoxyline and eosin; $\mathrm{H}_{2} \mathrm{~S}$ : Hydrogen sulphide; HBSS: Hank's balanced salt solution; HR: Heart rate; HRV: Heart rate variability; LOX: Lipoxygenase; MAPK: Mitogen activated-protin kinase; MDSCs: Myeloid derived suppressor cells; MEC: Myoepithelail cell; MNU-n: Methyl-nnitrosourea; MOMP: Mitochondrial membrane permeabilization; NO: Nitric oxide; PC: Protein carbonyl; PDE: Phosphodiesterase; ROS: Reactive oxygen species; SEM: Scanning electron microscopy; SOD: Superoxide dismutase; TBARs: Thiobarbituric acid reactive substances; TMPD- N,N,N'N': Tetramethylp-phenylenediamine

\section{Acknowledgements}

We appreciate the hard work of the colleagues at the university who provide us all the facilities for completion of the study.

\section{Authors' contributions}

MS and SK carried out the bench work; SR performed the immunoblotting assay; SA, ASS and NA perform the statistical analysis of the data; GK perceived the idea, designed and supervised the whole study, prepared and proof read the final manuscript. All authors have read and approved the manuscript.

\section{Funding}

MS received fellowship from University Grants Commission New Delhi (RGNF-2013-14-SC-UTT-38150). The fellowship helped MS to purchase all the required chemicals and drugs specified in the present study.

\section{Availability of data and materials}

The datasets used and analysed during the current study are available from the corresponding author on reasonable request.

\section{Ethics approval and consent to participate}

The study has been conducted according to the guidelines of CPCSEA for laboratory Animals and Ethics, Government of India (IAEC/SHIATS/PA16III/ SSPG19).

\section{Consent for publication}

Not applicable.

\section{Competing interests}

The authors declare that they have no competing interests.

\section{Author details}

'Department of Pharmaceutical Sciences, Babasaheb Bhimrao Ambedkar University, (A Central University), Vidya Vihar, Raebareli road, Lucknow, UP 226 025, India. ${ }^{2}$ Department of Pharmaceutical Sciences, King Faisal University, Al-Ahsa, Saudi Arabia. ${ }^{3}$ Department of Pharmacology, College of Pharmacy, Prince Sattam Bin Abdulaziz University, Al-Kharj, Kingdom of Saudi Arabia.

Received: 11 February 2019 Accepted: 11 September 2019

Published online: 24 October 2019

\section{References}

1. Chang JC. Cancer stem cells: role in tumor growth, recurrence, metastasis, and treatment resistance. Medicine. 2016;95(Suppl 1):S20-5.

2. Kumazoe M, Kim Y, Bae J, Takai M, Murata M, Suemasu Y, Sugihara K, Yamashita S, Tsukamoto S, Huang Y. Phosphodiesterase 5 inhibitor acts as a potent agent sensitizing acute myeloid leukemia cells to 67-kDa laminin receptor-dependent apoptosis. FEBS Lett. 2013;587(18):3052-7.

3. Catalano S, Campana A, Giordano C, Győrffy B, Tarallo R, Rinaldi A, Bruno G, Ferraro A, Romeo F, Lanzino M. Expression and function of phosphodiesterase type 5 in human breast cancer cell lines and tissues: implications for targeted therapy. Clin Cancer Res. 2016;22(9):2271-82.

4. Weed DT, Vella JL, Reis IM, Adriana C, Gomez C, Sargi Z, Nazarian R, Califano J, Borrello I, Serafini P. Tadalafil reduces myeloid-derived suppressor cells and regulatory $T$ cells and promotes tumor immunity in patients with head and neck squamous cell carcinoma. Clin Cancer Res. 2015;21(1):39-48.

5. Shi Z, Tiwari AK, Ashby Jr CR, Chen Z-S, Fu L-W: Anti-cancer Role of Phosphodiesterase-5 Inhibitors.

6. Thornton TM, Rincon M. Non-classical p38 map kinase functions: cell cycle checkpoints and survival. Int J Biol Sci. 2009;5(1):44.

7. Serafini P, Meckel K, Kelso M, Noonan K, Califano J, Koch W, Dolcetti L, Bronte V, Borrello I. Phosphodiesterase-5 inhibition augments endogenous antitumor immunity by reducing myeloid-derived suppressor cell function. $J$ Exp Med. 2006;203(12):2691-702.

8. Barone I, Giordano C, Bonofiglio D, Andò S, Catalano S. Phosphodiesterase type 5 and cancers: progress and challenges. Oncotarget. 2017;8(58):99179.

9. Tiwari AK, Chen SZ. Repurposing phosphodiesterase-5 inhibitors as chemoadjuvants. Front Pharmacol. 2013;4:82. https://doi.org/10.3389/fphar. 2013.00082.

10. Saravani R, Galavi HR, Shahraki A. Inhibition of Phosphodiesterase 5 and Increasing the Level of Cyclic Guanosine 3', 5' Monophosphate by Hydroalcoholic Achillea wilhelmsii C. Koch Extract in Human Breast Cancer Cell Lines MCF-7 and MDA-Mb-468. Breast Cancer Basic Clin Res. 2017;11: 1178223417690178 .

11. Mishra RK, Sammi SR, Rawat JK, Roy S, Singh M, Gautam S, Yadav RK, Devi U, Ansari MN, Saeedan AS. Palonosetron attenuates 1, 2-dimethyl hydrazine induced preneoplastic colon damage through downregulating acetylcholinesterase expression and up-regulating synaptic acetylcholine concentration. RSC Adv. 2016;6(46):40527-38.

12. Kaithwas G, RAWAT JK, Roy S, Singh M, Gautam S, Yadav R, Ansari MN, Aldossary SA, Saeedan AS. Transcutaneous vagus nerve stimulation regulates the cholinergic anti-inflammatory pathway to counteract 1, 2dimethyl hydrazine induced colon carcinogenesis in albino wistar rats. Front Pharmacol. 2019;10:353.

13. De Assis S, Warri A, Cruz Ml, Hilakivi-Clarke L. Changes in mammary gland morphology and breast cancer risk in rats. J Vis Exp. 2010;44. https://doi.org/ $10.3791 / 2260$

14. Singh M, Devi U, Roy S, Gupta PS, Kaithwas G. Chemical activation of prolyl hydroxylase-2 by BBAP-1 down regulates hypoxia inducible factor-1a and fatty acid synthase for mammary gland chemoprevention. RSC Adv. 2018; 8(23):12848-60.

15. Gautam S, Singh P, Singh M, Roy S, Rawat JK, Yadav RK, Devi U, Gupta PS, Saraf SA, Kaithwas G. Rifaximin, a pregnane X receptor (PXR) activator regulates apoptosis in a murine model of breast cancer. RSC Adv. 2018;8(7): 3512-21.

16. Devi U, Singh M, Roy S, Tripathi AC, Gupta PS, Saraf SK, Ansari MN, Saeedan AS, Kaithwas G. PHD-2 activation: a novel strategy to control HIF-1a and mitochondrial stress to modulate mammary gland pathophysiology in ER+ subtype. Naunyn Schmiedeberg's Arch Pharmacol. 2019;392:1-18.

17. Roy S, Rawat AK, Sammi SR, Devi U, Singh M, Gautam S, Yadav RK, Rawat JK, Singh L, Ansari MN. Alpha-linolenic acid stabilizes HIF-1 $a$ and 
downregulates FASN to promote mitochondrial apoptosis for mammary gland chemoprevention. Oncotarget. 2017:8(41):70049.

18. Devi U, Singh M, Roy S, Gupta PS, Ansari MN, Saeedan AS, Kaithwas G Activation of prolyl hydroxylase-2 for stabilization of mitochondrial stres along with simultaneous downregulation of HIF-1a/FASN in ER+ breast cancer subtype. Cell Biochem Funct. 2019:37(4):216-27.

19. Rani V, Gautam S, Rawat JK, Singh M, Devi U, Yadav RK, Roy S, Kaithwas G. Effects of minocycline and doxycycline against terbutaline induced early postnatal autistic changes in albino rats. Physiol Behav. 2018;183:49-56.

20. Kaithwas G, Majumdar DK. In vitro antioxidant and in vivo antidiabetic antihyperlipidemic activity of linseed oil against streptozotocin-induced toxicity in albino rats. Eur J Lipid Sci Technol. 2012;114(11):1237-45.

21. Rani A, Roy S, Singh M, Devi U, Yadav RK, Gautam S, Rawat JK, Ansari MN, Saeedan AS, Prakash A. a-Chymotrypsin regulates free fatty acids and UCHL1 to ameliorate $\mathrm{N}$-methyl nitrosourea induced mammary gland carcinoma in albino wistar rats. Inflammopharmacology. 2016;24(5):277-86.

22. Tiwari V, Singh M, Rawat JK, Devi U, Yadav RK, Roy S, Gautam S, Saraf SA Kumar V, Ansari N. Redefining the role of peripheral LPS as a neuroinflammatory agent and evaluating the role of hydrogen sulphide through metformin intervention. Inflammopharmacology. 2016;24(5):253-64.

23. Manral C, Roy S, Singh M, Gautam S, Yadav RK, Rawat JK, Devi U, Ansari MN, Saeedan AS, Kaithwas G. Effect of $\beta$-sitosterol against methyl nitrosoureainduced mammary gland carcinoma in albino rats. BMC Complement Altern Med. 2016;16(1):260

24. Gautam S, Rawat AK, Sammi SR, Roy S, Singh M, Devi U, Yadav RK, Singh L, Rawat JK, Ansari MN. DuCLOX-2/5 inhibition attenuates inflammatory response and induces mitochondrial apoptosis for mammary gland chemoprevention. Front Pharmacol. 2018;9:314.

25. Yadav S, Tiwari V, Singh M, Yadav RK, Roy S, Devi U, Gautam S, Rawat JK, Ansari MN, Saeedan AS. Comparative efficacy of alpha-linolenic acid and gamma-linolenic acid to attenuate valproic acid-induced autism-like features. J Physiol Biochem. 2017;73(2):187-98.

26. Kruger NJ. The Bradford method for protein quantitation. In: The protein protocols handbook. Humana Press: Springer; 2002. p. 15-21.

27. Roy S, Singh M, Rawat A, Devi U, Gautam S, Yadav RK, Rawat JK, Ansari MN, Saeedan AS, Kumar D. GLA supplementation regulates PHD2 mediated hypoxia and mitochondrial apoptosis in DMBA induced mammary gland carcinoma. Int J Biochem Cell Biol. 2018;96:51-62.

28. Golding BT, Bleasdale C, McGinnis J, Müller S, Rees HT, Rees NH, Farmer PB, Watson WP. The mechanism of decomposition of $\mathrm{N}$-methyl-N-nitrosourea $(\mathrm{MNU})$ in water and a study of its reactions with 2'-deoxyguanosine, 2'deoxyguanosine 5'-monophosphate and d (GTGCAC). Tetrahedron. 1997; 53(11):4063-82.

29. Cameron AC, Touyz RM, Lang NN. Vascular complications of cancer chemotherapy. Can J Cardiol. 2016;32(7):852-62.

30. Hutchings DC, Anderson SG, Caldwell JL, Trafford AW. Phosphodiesterase-5 inhibitors and the heart: compound cardioprotection? Heart. 2018. https:// doi.org/10.1136/heartjnl-2017-312865.

31. Bolisetty S, Jaimes EA. Mitochondria and reactive oxygen species: physiology and pathophysiology. Int J Mol Sci. 2013;14(3):6306-44.

32. Reuter S, Gupta SC, Chaturvedi MM, Aggarwal BB. Oxidative stress, inflammation, and cancer: how are they linked? Free Radic Biol Med. 2010 49(11):1603-16.

33. Kukreja RC, Salloum FN, Das A. Cyclic guanosine monophosphate signaling and phosphodiesterase-5 inhibitors in cardioprotection. J Am Coll Cardiol. 2012;59(22):1921-7.

34. Peak TC, Richman A, Gur S, Yafi FA, Hellstrom WJ. The role of PDE5 inhibitors and the NO/cGMP pathway in cancer. Sex Med Rev. 2016:4(1):74-84

35. Kashfi K. Anti-cancer activity of new designer hydrogen sulfide-donating hybrids. Antioxid Redox Signal. 2014;20(5):831-46.

36. Thomas DD, Ridnour LA, Isenberg JS, Flores-Santana W, Switzer CH, Donzelli S, Hussain P, Vecoli C, Paolocci N, Ambs S. The chemical biology of nitric oxide: implications in cellular signaling. Free Radic Biol Med. 2008;45(1):18-31.

37. Tseng H-S, Chen L-S, Kuo S-J, Chen S-T, Wang Y-F, Chen D-R. Tumor characteristics of breast cancer in predicting axillary lymph node metastasis. Med Sci Monit. 2014;20:1155.

38. Gautam S, Roy S, Ansari MN, Saeedan AS, Saraf SA, Kaithwas G. DuCLOX-2/5 inhibition: a promising target for cancer chemoprevention. Breast Cancer. 2017;24(2):180-90.

39. Bell RA, Megeney LA. Evolution of caspase-mediated cell death and differentiation: twins separated at birth. Cell Death Differ. 2017;24(8):1359.
40. Xia H, Ma S, Wang S, Sun G. Meta-analysis of saturated fatty acid intake and breast cancer risk. Medicine. 2015;94(52):e2391.

41. MacLennan M, Ma DW. Role of dietary fatty acids in mammary gland development and breast cancer. Breast Cancer Res. 2010;12(5):211.

42. Klutzny S, Anurin A, Nicke B, Regan JL, Lange M, Schulze L, Parczyk K, Steigemann P. PDE5 inhibition eliminates cancer stem cells via induction of PKA signaling. Cell Death Dis. 2018;9(2):192.

43. Roy S, Singh M, Sammi SR, Pandey R, Kaithwas G. ALA-mediated biphasic downregulation of alpha-7nAchR/HIF-1alpha along with mitochondrial stress modulation strategy in mammary gland chemoprevention. J Cell Physiol. 2019;234(4):4015-29.

\section{Publisher's Note}

Springer Nature remains neutral with regard to jurisdictional claims in published maps and institutional affiliations.
Ready to submit your research? Choose BMC and benefit from:

- fast, convenient online submission

- thorough peer review by experienced researchers in your field

- rapid publication on acceptance

- support for research data, including large and complex data types

- gold Open Access which fosters wider collaboration and increased citations

- maximum visibility for your research: over $100 \mathrm{M}$ website views per year

At BMC, research is always in progress.

Learn more biomedcentral.com/submissions 